\title{
Tourists' Perception towards Cox's Bazar Sea Beach in Bangladesh as a Tourist Destination
}

\author{
Prodip Dey ${ }^{1}$, Shamsu Uddin ${ }^{2}$, \& Md. Kamrul Hasan ${ }^{3}$
}

${ }^{1}$ Visiting Lecturer, Faculty of Business Administration and Social Sciences, Sylhet International University, Sylhet, BANGLADESH

${ }^{2}$ Senior Lecturer, Department of Business Administration, Leading University, Sylhet, BANGLADESH

${ }^{3}$ Assistant Professor, Faculty of Business Administration and Social Sciences, Sylhet International University, Sylhet, BANGLADESH

\begin{abstract}
The study was carried out on Cox's Bazar sea beach area, the world longest sea beach and the tourist capital of Bangladesh. The purpose of the present study is to investigate the tourists' perception towards various facilities and services at Cox's Bazar sea beach as a tourists' destination. The study was based on primary as well as secondary data; applied quantitative method and 308 questionnaires were used. The factor analysis was conducted to create correlated variable composites from the original attributes. The results of the study stated that tourists' perception is favorable on Factor 1, Natural Beauty and Restful Atmosphere, Factor 3, Accommodation and security, Factor 4, Hospitality and information and Factor 6, Shopping and activities and tourists' perception is unfavorable on Factor 2, Hygiene and Sanitation and Factor 5, emergency and caring services. The findings of the current research suggest that there are statistically significant differences in tourists' perception with respects of respondents' demographic characteristics such as respondents' gender, age, occupation and education in some services and facilities at Cox's Bazar. The findings suggest that the tourism market players, managers and policy makers should ensure up to the mark services with unfavorable factors and differentiated marketing strategies should be stressed and executed by the relevant parties. Therefore, the findings of the study also provided theoretical and practical implications for the planners, marketers and tourism authorities of Cox's Bazaar in formulating strategies to maintain or enhance their competitiveness.
\end{abstract}

Keywords: Beach tourism, Tourists' perception, Natural beauty, Hygiene and Sanitation facility, Factor Analysis, Cox's Bazar Sea beach

JEL Classification Code: M31

\section{INTRODUCTION}

Derception is the process by which individuals select, 1 organize, and interpret stimuli into a meaningful and coherent picture of the world. Individuals act and react on the basis of their perceptions, not on the basis of objective reality. Individuals make decisions and take actions based on what they perceive to be reality. In marketing, the role of perception in consumer behavior is all about recognizing how consumers view a company's product or service. People wish to be perceived as having the ability to make the "right" choices and pick the "right" products. Marketers use perception to target people's need to fit in and be part of a larger group of discerning consumers. Depending on consumers' perception, each product can be received quite differently: favorably, less favorably or not at all. It will help to positioning marketers' product and brand relative to other products and brands in the consumers' mind. Marketers must distinguish their messages from their competitors' to grab consumers' attention.

Cox's Bazar sea beach of Bangladesh is the world longest sea beach. It is the tourist capital of Bangladesh having $120 \mathrm{~km}$. Beach slopping gently down to the blue waters of the Bay of Bengal against the picturesque background of a chain of hill covered by deep green forests. This type of smooth and straight sea beach is hardly seen in any other place of the world. Miles of golden sands, towering cliffs, surfing waves, rare conch shells, and delightful seafood are the specialties of Cox's Bazar sea beach.

Every year a large number of tourists from home and abroad come to visit this beach for enjoyment. During the peak season (November to March) nearly 2 millions of tourists' visit Cox's Bazar and the Labonee beach at Cox's Bazar is reportedly one of the most heavily visited tourist destinations in the country (Daily maximum visitors as high as 30,000). At that time all hotels, motels and guest houses remain totally filled up and even some visitors spend their nights inside the vehicle because no seats are available in the hotels [02]. There are many hotels, motels, cottages, restaurants, rest houses and guest houses have been developed for tourists from Labonee to Kalatali and near area in Cox's Bazar. Now Cox's Bazar has nearly 154 restaurants for food supply to the tourists and each of them has on an average of 22 assistants. The total figure of assistants stands for 3388 people. Then for tourists Cox's Bazar has 220 hotels and guest houses, and each employed on average 20 people and thus the total account (number) is 4400. Again altogether Cox's Bazar tourism registers 54 tour operators and guide houses in which on average 15 people work in each company and thus total figure is 810 persons working in the tour operators. Again 
on average 5000 construction workers are working and maintaining family by building hotels, motels and guesthouses and so on. Many local people including students are working as tourist guides, doing jhinuk business, renta-car business, land business, opening departmental stores, hiring umbrella at the sea beach locally known as 'kit-kot', driving small playing vehicles on/at the beach locally known as 'z-ski' and so on. A large number of people are also involved in fishing and collecting seafood and sea products for their livelihood. Altogether around 10000 people are working in the tourism sector in Cox's Bazar and each person maintains a family of 6 persons, then this tourism industry is giving food to around 60,000 people ${ }^{[02] .}$ As world's longest sea beach Cox's Bazar is experiencing huge growth in tourism since $1990{ }^{[02]}$. Now the economy of Cox's Bazar depends on tourism. From general observation it is understood that tourism has brought a big change in this area. On economic front, local community people and other stakeholders like investors, hoteliers, tour operators and so on are seemingly benefited from tourism and its economy is quite good compared with other backward area. So it is clear to all the contribution of Cox's Bazar sea beach in the local economy as well as national economy of Bangladesh. ${ }^{[02]}$ The flow of economic contribution, growth and sustainability depends on number of tourist arrival and facility consumed. The present facilities provided by the responsible authorities are how much sufficient to the tourists should to be investigated. What are the tourists' perceptions towards the various facilities and services are to be understood. The objective of the present study is to investigate the tourists' perceptions towards various facilities and services and to identify different beach tourist segments based on a set of socio-demographic variables and to further analyze differences in perception in terms of socio-demographic behavior. Results may help to understand the beach tourism market and contribute to an improved target marketing to each group, simultaneously positioning products in the minds of consumers. So/As far we know there is no study has been conducted to find out these issues. These are the research gaps where needs special attention. The present study is an ample step to cover this gap. From this context this study has been taken by the researchers.

\section{LiteRATURE REVIEW}

Khan. R. Mizan and Haque Mahfuzul (2006), Islam Faridul and Islam Nazrul (2004), Hasan (1992), Hall and Page (2000) conducted the four elaborate studied covering the tourism and tourism environment in Bangladesh. The study focuses tourism potentiality, major problems and prospects of tourism, marketing strategies of tourism industry, foreign tourist arrival trend in Bangladesh. Kamal \& Chowdhury (1993), Hasan \& Chowdhury (1995) also conducted studies on the basis of tourism related services. In fact these were the studies based on performance of tourism related services as well as the contribution to the development of the country's tourism industry. Some others studies have been conducted by Hossain and Firozza-

Copyright (C) 2013, Asian Business Consortium | ABR man (2003), Syed Ahsanul Alam and Mohammad Shamsuddoha (2003), Mohammad Shamsuddoha (2005), Md. Jakir Hossain (2006), Dr. Zakria Lincoln(2008). These studies focused that the significance of tourism is viewed from many angles like economic, social, cultural, political, etc. Shah Azam, et al, conducted a study on factors affecting choose Bangladesh as a tourist destination. The study shows that service quality, natural beauty, security and shopping facility are statistically significant in explaining the intention to select a tour destination in Bangladesh. Another study conducted by Mir Abdul Sofique and Jannat Ara Parveen (2009) and Sheikh Saleh Ahammed (2010) are directly relatted to Cox's Bazaar tourism regarding economic and socio-cultural e/affect of tourism. So far researchers of this study know there is no rich study has been conducted yet covering the understanding of existing image of beach tourism in Bangladesh specially Cox's Bazar as a world longest sea beach as well as tourist destination.

\section{ObJectives OF THE STUdY}

The major objectives of the study are:

3.1 To identify the tourists' perception and attitude towards the various facilities and services at Cox's Bazar sea beach as a tourist destination.

3.2 To understand how tourists' perception varies on various factors by tourists' socio-demographic characters such as age, gender, education and profession.

\section{Hypothesis OF THE STUdY}

$\mathrm{H}_{1}: \mathrm{H}_{0}$ : The perception of tourists' are not differed towards the various facilities and services by gender

$\mathrm{H}_{2}: \mathrm{H}_{0}$ : perception of tourists' are not differed towards the various facilities and services by age

$\mathrm{H}_{3}: \mathrm{H}_{0}$ : perception of tourists' are not differed towards the various facilities and services by educational level

$\mathrm{H}_{4}: \mathrm{H}_{0}$ : The perception of tourists' are not differed towards the various facilities and services by different professional level

$\mathrm{H}_{5}: \mathrm{H}_{0}$ : The perception of tourists' are not differed towards the various facilities and services by income level

\section{Methodology of THE Study}

The study has been carried out on Cox's Bazar sea beach area in Bangladesh. The reason for choosing this area is that it is the world longest sea beach and tourist capital of Bangladesh as well as there is no earlier research carried out in this regards. The sample population for this study was composed of tourists who visited Cox's Bazaar sea beach in between 07 May 2011 and 21 May 2011. A convenient sampling technique was used to collect primary data by means of a survey, using self-administered questionnaires distributed to visitors at the study area. The structured questionnaire was constructed with different attributes using a scale of 1 to 5 ( 5 being highly favorable and 1 being not favorable at all) to each attribute selected 
for the different facilities and services of Cox's Baazar sea beach. Out of 320 sample questionnaires 308 were useable questionnaires with a response rate of almost $98 \%$. Appropriate statistical analyses such as frequencies, descriptive, analysis of Variance (ANOVA), factor analysis were used to satisfy the major objectives. These statistical analyses were conducted using the Statistical Package for Social Science (SPSS) software. The researchers collected secondary data from relevant research reports and publications, newspapers, books, websites and published materials of BPC, the ministry of tourism and aviation.

\section{Result AND Discussion Of the Study}

The analysis and discussion of the study have been divided into three points of view:

1. To find the socio-demographic characteristics of the tourists;

2. Assessing tourists' perception towards various attributes and factors at Cox's Bazar sea beach as a tourist destination;

3. To find the variations in perception with respect to tourists' demographic character.

\subsection{Respondents' Socio-Demographic Profile}

The theory of consumer behavior for a service sector points out that customers' perceptions, choice behavior, buying behavior and levels of satisfaction are influenced by the customer's background, characteristics and external stimuli (Fornell C, 1992). Respondents' sociodemographic profiles shows out of a total of 308 respondents listed for analysis, 249 (81.3\%) were male and 61 $(18.8 \%)$ were female. Data were collected from different age group. Large group of respondents were from 18-40 $(58.7 \%)$ age group, followed by $41-60(32.2 \%)$ age group. Surprisingly, highest $49.9 \%$ of the respondents have completed graduation level followed by $35.6 \%$ secondary level. In addition, $34.6 \%$ respondents were students, where as $27.7 \%$ respondents answered that they were businessman, followed by $21.6 \%$ are private job holders and $10.1 \%$ are government service holders and others category includes self employed in different professions at the time of the survey. The sample distribution provides a clear idea (that) male, young with graduate education and students are the main visitors at Cox's Bazaar sea beach and the prefer most.

\subsection{ASSESSING TOURISTS' PERCEPTION TOWARDS VARIOUS ATTRIBUTES AT COX'S BAZAR SEA BEACH AS A TOURIST DESTINATION}

The table 1 revealed that out of 33 attributes tourists' showed highly positive attitude on only five attributes which had highest mean score $<(M=4.00)$ and 18 attributes scored $>3$ and 10 attributes had lowest scored $<3$ respectively.
Table 1: shows the opinion given to the attributes by the tourist

\begin{tabular}{|c|c|c|c|c|}
\hline \multirow[b]{2}{*}{ Attributes } & \multirow[b]{2}{*}{$\mathbf{N}$} & \multicolumn{3}{|c|}{ Result } \\
\hline & & Mean & SD & V \\
\hline Natural attractions of the beach & 308 & 4.47 & 0.64 & 0.41 \\
\hline Scenery and views of the beach area & 302 & 4.47 & 0.63 & 0.40 \\
\hline Scenery of sunset & 306 & 4.16 & 0.82 & 0.67 \\
\hline Availability of local transportations & 306 & 4.15 & .694 & 0.65 \\
\hline Enjoying sea waves & 306 & 4.00 & 0.91 & 0.83 \\
\hline Transportation cost & 305 & 3.97 & .798 & 0.73 \\
\hline Service quality of residential hotels & 306 & 3.42 & 0.77 & 0.60 \\
\hline Service quality of transportations & 307 & 3.39 & 0.82 & 0.68 \\
\hline $\begin{array}{l}\text { Local people behavior and hospi- } \\
\text { tality towards tourists }\end{array}$ & 305 & 3.36 & 0.95 & 0.91 \\
\hline Road quality in the spot area & 306 & 3.32 & 0.61 & 0.37 \\
\hline $\begin{array}{l}\text { Financial, physical and other safety } \\
\text { and security }\end{array}$ & 303 & 3.31 & 1.10 & 1.22 \\
\hline Food quality at restaurants & 298 & 3.25 & 0.83 & 0.69 \\
\hline Price of Accommodations & 302 & 3.25 & 1.02 & 1.05 \\
\hline Service quality of restaurants & 305 & 3.19 & 0.86 & 0.74 \\
\hline $\begin{array}{l}\text { Local product, sea products shop- } \\
\text { ping facilities }\end{array}$ & 306 & 3.17 & 0.78 & 0.62 \\
\hline $\begin{array}{l}\text { Easy, relaxed and noise free envi- } \\
\text { ronment }\end{array}$ & 305 & 3.16 & 1.00 & 1.00 \\
\hline $\begin{array}{l}\text { Financial institution for withdraw- } \\
\text { ing instant cash }\end{array}$ & 305 & 3.15 & .650 & 0.98 \\
\hline Swimming, surfing, and boating facilities & 305 & 3.15 & 1.10 & 1.21 \\
\hline Pollution free nature and environment & 305 & 3.12 & 1.07 & 1.15 \\
\hline $\begin{array}{l}\text { Cost of surfing, boating, driving } \\
\text { and horse riding }\end{array}$ & 298 & 3.11 & 1.072 & 1.16 \\
\hline $\begin{array}{l}\text { Playing, driving and horse riding } \\
\text { facilities on the beach }\end{array}$ & 306 & 3.10 & .841 & 1.07 \\
\hline $\begin{array}{l}\text { Available information about Cox's } \\
\text { bazaar }\end{array}$ & 306 & 3.08 & 1.07 & 1.15 \\
\hline $\begin{array}{l}\text { Amalgamation views of sea, sky } \\
\text { and hills }\end{array}$ & 304 & 3.00 & 0.96 & 0.93 \\
\hline Food price at restaurant & 306 & 2.98 & 1.052 & 0.99 \\
\hline Online hotel booking facility & 305 & 2.98 & .942 & 0.86 \\
\hline Local information centre & 302 & 2.64 & .871 & 1.09 \\
\hline $\begin{array}{l}\text { Cleanliness of public areas nearest } \\
\text { the beach }\end{array}$ & 306 & 2.63 & 0.90 & 0.81 \\
\hline $\begin{array}{l}\text { Health and Medical facilities to } \\
\text { serve tourists }\end{array}$ & 307 & 2.59 & .882 & 0.83 \\
\hline $\begin{array}{l}\text { Watch tower facility for enjoying } \\
\text { sea view and }\end{array}$ & 304 & 2.44 & 1.09 & 1.19 \\
\hline $\begin{array}{l}\text { Tourist caring facility such as per- } \\
\text { sonal care, child care }\end{array}$ & 306 & 2.38 & 0.89 & 0.80 \\
\hline $\begin{array}{l}\text { Public and Private toilet facilities } \\
\text { nearest the beach }\end{array}$ & 307 & 2.37 & 0.99 & 0.98 \\
\hline Waste disposal facility & 302 & 2.23 & .903 & 0.72 \\
\hline $\begin{array}{l}\text { Emergency service such as lifeboat, } \\
\text { ambulance, fast aid }\end{array}$ & 306 & 2.17 & 0.80 & 0.65 \\
\hline
\end{tabular}

[Mean ranges from 1 (Not at all favorable) to 5 (Highly favorable)] 
The highest mean score regarding various services and facilities occurred in the case of item natural attraction and scenery and views of the beach area $(\mathrm{M}=4.47)$, followed by the Scenery of sunset $(\mathrm{M}=4.16)$ and Enjoying sea waves $(\mathrm{M}=4.00)$ and lowest attributes was emergency service such as lifeboat, ambulance, fast aid $(\mathrm{M}=2.17)$. Attributes mean scores below 2.75 are interpreted as poor; scores between 2.75 to 3.25 indicated average; scores 3.25 to 4.00 were interpreted as good and above 4.00 excellent. $^{[04]}$

\subsection{DiMENSIONS OF DESTINATION FACILITIES AND SERVICES at CoX's Bazar SEA BeAch}

After identifying individual perception on different facilities and services hold by the tourists, the authors tried to group them under some factors by employing "Factor Analysis" through SPSS 19.0. Factor Analysis was undertaken to create correlated variable composites from the original 33 attributes and to identify a smaller set of dimensions, or factors that explain most of the variances between the attributes. The derived factor scores are then applied in subsequent analysis. In this study, factors are retained only if they had values greater than or equal to 1.0 of eigenvalue and a factor loading $>0.4$. The principal components factor method was used to generate the initial solution. The overall significance of the correlation matrix was 0.000 , with a Bartlett test of sphericity value of 1545.10 with degree of freedom 261 . The statistical probability and the test indicated that there was a significant correlation between the variables, and the use of factor analysis was appropriate. The Kaiser-Meyer-Olkin overall measure of sampling adequacy was 0.789 , which was meritorious (Hair, Anderson, and Black 1999).

Table 2 illustrates the results of the factor analysis. The eigenvalues suggested that six-factor solution explained $62.67 \%$ of the overall variance before the rotation. From the varimax-rotated factor matrix, six factors with 33 variables were defined that loaded most heavily on them (loading $>0.4$ ). The communality of each variable ranged from 0.461 to 0.810 . To test the reliability and internal consistency of each factor, the Cronbach's alpha of each was determined. The results showed that the alpha coefficients ranged from 0.638 to 0.818 for the six factors. The results were considered more than reliable, since 0.50 is the minimum value for accepting the reliability test (Nunnally, 1967).

Table 2, Factor Analysis Result

\begin{tabular}{|l|l|l|l|}
\hline $\begin{array}{l}\text { Factors relating to } \\
\text { Image }\end{array}$ & $\begin{array}{l}\text { Factor } \\
\text { Load } \\
\text { ing }\end{array}$ & $\begin{array}{l}\text { Comm } \\
\text { unali } \\
\text { ties }\end{array}$ & Results \\
\hline \hline $\begin{array}{l}\text { Factor 1: Natural } \\
\text { Beauty and Restful } \\
\text { Atmosphere }\end{array}$ & & & \\
$\begin{array}{l}\text { Scenery and views of } \\
\text { the beach }\end{array}$ & .857 & .810 & $\begin{array}{l}\text { Eigenvalue 5.05 } \\
\text { Variance explained } \\
\text { Natural 21.97 } \\
\text { of the beach }\end{array}$ \\
\begin{tabular}{l} 
Cronbach's alpha $\alpha$ \\
\hline
\end{tabular}
\end{tabular}

Scenery of sunset

Enjoying sea waves

Pollution free nature

and environment

Amalgamation

views of sea, sky and

hills

Easy, relaxed and

noise free environ-

ment

Factor 2: Hygiene and Sanitation

Watch tower facility for enjoying sea view

Public and Private toilet facilities near-

est the beach

Cleanliness of public

areas nearest the

beach

Service quality of restaurants

Waste disposal facili-

ty

Dress change facility nearest the beach

Factor 3: Accommodation and Security

Financial, physical and other safety and security

Price of the accommodation

Service quality of

residential hotels

Service quality of

transportations

Swimming, surfing,

and boating facilities

Price of foods at the

restaurant

Factor 4:Hospitality and Information

Local people behavior and hospitality towards tourists

Online information

about Cox's bazaar

Local information

centre

Food quality at res-

taurants

Online hotel booking

facility

Factor 5: Emergency and Caring services

Tourist caring facility such as personal

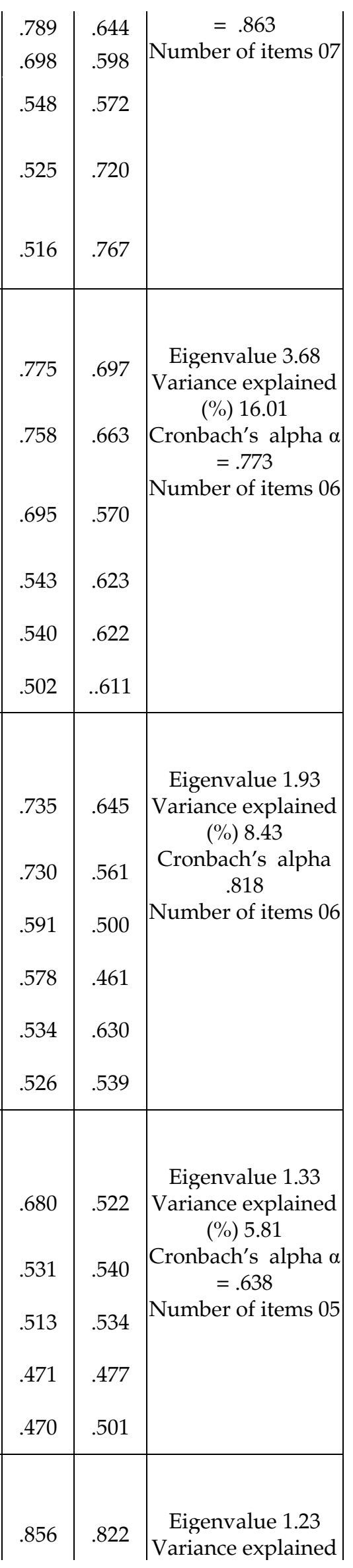

57 | P a g e 


\begin{tabular}{|c|c|c|c|}
\hline $\begin{array}{l}\text { care, child care etc. } \\
\text { Emergency service } \\
\text { such as lifeboat, am- } \\
\text { bulance, fast aid ser- } \\
\text { vice } \\
\text { Health and Medical } \\
\text { facilities to serve } \\
\text { tourists } \\
\text { Financial institution } \\
\text { for withdrawing } \\
\text { instant cash } \\
\text { Available local } \\
\text { transportations } \\
\text { Transportation cost }\end{array}$ & .6 .88 & $\begin{array}{l}.716 \\
.678\end{array}$ & $\begin{array}{c}(\%) 5.34 \\
\text { Cronbach's alpha } \alpha \\
=.777 \\
\text { Number of items } 06\end{array}$ \\
\hline $\begin{array}{l}\text { Factor 6: Shopping } \\
\text { and Activities } \\
\text { Playing, driving and } \\
\text { horse riding facilities } \\
\text { on the beach } \\
\text { Local product, sea } \\
\text { products shopping } \\
\text { facilities } \\
\text { Cost of surfing, boat- } \\
\text { ing, driving and } \\
\text { horse riding } \\
\text { Road quality in the } \\
\text { spot area }\end{array}$ & .613 & .503 & $\begin{array}{c}\text { Eigenvalue } 1.17 \\
\text { Variance explained } \\
(\%) 5.10 \\
\text { Cronbach's alpha } \alpha \\
=.644 \\
\text { Number of items } 04\end{array}$ \\
\hline
\end{tabular}

Extraction Method: Principal Component Analysis, Rotation Method: Varimax with Kaiser Normalization

Bartlett's Test of Sphericity: $p=0.000(x 2=1545.10, d f=261), K M O=0.789$

Factor 1 was labeled as Natural Beauty and Restful Atmosphere which consisted of seven items namely scenery and views of the beach, natural attractions of the beach, scenery of sunset, enjoying sea waves, pollution free nature and environment, amalgamation views of sea, sky and hills and easy, relaxed and noise free environment. This factor explains 21.97 percent of the variance in the data with an eigenvalue of 5.05. $(\alpha=0.863)$.

Factor 2 was termed as Hygiene and Sanitation for 16.01percent of the variance with an eigenvalue of 3.68 this factor is loaded with six items with relation to watch tower facility for enjoying sea view, public and private toilet facilities nearest the beach, cleanliness of public areas nearest the beach, waste disposal facility, dress change facility and service quality of restaurants. $(\alpha=0.773)$

Factor $3(\alpha=0.818)$ was named as Accommodation and Security consisting of six items namely financial, physical and other safety and security, price of the accommodation, service quality of residential hotels, service quality of transportations and swimming, surfing, and boating facilities. This factor accounts for 8.43 percent of the variance with an eigenvalue of 1.93 .

Factor 4 with an eigenvalue of 1.33 and 5.81 percent of the variance is called Hospitality and Information is classified into five activities namely local people behavior and hospitality towards tourists, information source about Cox's Bazaar, online hotel booking facility and food quality at restaurants. $(\alpha=0.638)$.

Factor 5 was labeled as Emergency and Caring services which accounted for 5.34 percent of the variance and 1.23 eigenvalue. This factor consisted of six factors viz. tourist caring facility such as personal care, child care etc. and emergency service such as lifeboat, ambulance, and fast aid service and others. $(\alpha=0.777)$.

Factor 6 named as Shopping and activities facility which consisted of sea beach activities facilities, local products, sea products shopping facilities and road quality in the spot area and. This factor accounted for 5.10 percent of the variance with 1.17 eigenvalue $(\alpha=0.644)$.

\subsection{TOURISTS' PERCEPTION TOWARDS THE VARIOUS FACILITIES AND SERVICES AT COX'S BAZAR SEA BEACH AS A TOURIST DESTINATION}

Table 3 revealed that tourists' overall perception towards the various facilities and services at Cox's Bazar sea beach as a tourist destination is favorable on factor 1, Natural Beauty and Restful Atmosphere (G. Mean=3.78), factor 3, Accommodation and security (G. Mean=3.30), factor 4, Hospitality and information (G. Mean=3.22) and factor 6, Shopping and activities facilities (G. Mean=3.25). On the other hand tourists' perception is unfavorable on factor 2, Hygiene and Sanitation (G. Mean=2.66) and factor 5, Emergency and Caring services (G. Mean=2.30).

Table 3. Tourists' overall perception

\begin{tabular}{|l|l|l|l|l|}
\hline $\begin{array}{c}\text { Factor } \\
\text { No. }\end{array}$ & \multicolumn{1}{|c|}{ Facilities \& Services } & N & Mean & STD \\
\hline Factor 1 & $\begin{array}{l}\text { Natural Beauty and Restful } \\
\text { Atmosphere }\end{array}$ & 208 & 3.7816 & .64525 \\
\hline Factor 2 & Hygiene and Sanitation & 208 & 2.6619 & .74268 \\
\hline Factor 3 & Accommodation and Security & 207 & 3.3085 & .66689 \\
\hline Factor 4 & Hospitality and Information & 208 & 3.2252 & .68448 \\
\hline Factor 5 & Emergency and Caring services & 208 & 2.3053 & .79814 \\
\hline Factor 6 & Shopping and activities & 208 & 3.2524 & .58565 \\
\hline
\end{tabular}

\subsection{DIFFERENCES IN TOURISTS' PERCEPTION WITH RESPECT TO TOURISTS' DEMOGRAPHIC PROFILE}

Analysis of variance (ANOVA) was used to analyze hypotheses and to determine whether there were differences among derived factors with respect to demographic characteristics.

$\mathrm{H}_{1}$ : $\mathrm{H}_{0}$ : The perception of tourists' are not differed towards the various facilities and services by gender

Analysis of variance (ANOVA) was used to analyze hypothesis 1. The results of one way ANOVA of the mean differences of tourist's perception on major facilities and services by demographic characteristics are summaraized following: 
Table 4. Results by Gender

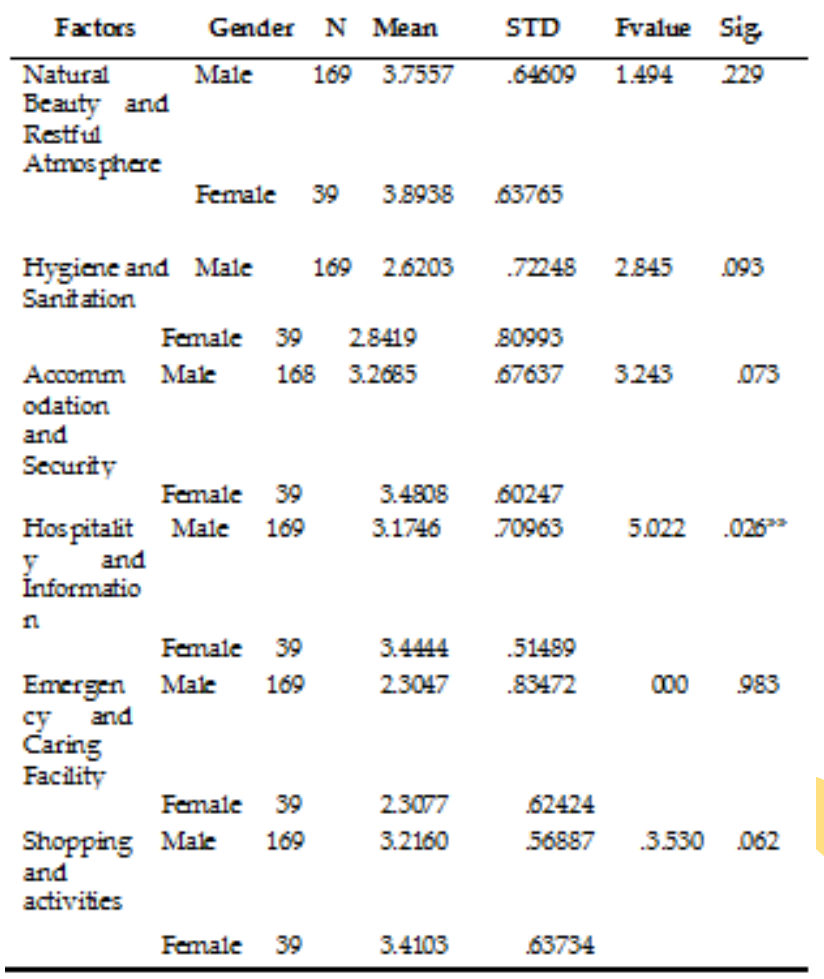

Significance at the 0.05 level

The results in the table 4 show the means, standard deviation and statistical significance of the mean differences. It is found that both male and female perceptions don't varies regarding all factors except Factor 3, Hospitality and information $(\mathrm{F}=5.02, \mathrm{p}=0.026)$. The female perception is more positive in this factor $(\mathrm{M}=3.44)$ than male $(\mathrm{M}=3.17)$. Thus, hypothesis 1 has been rejected for factor 4 and accepted for others.

$\mathrm{H}_{2}$ : $\mathrm{H}_{0}$ : The perception of tourists' are not differed towards the various facilities and services by age

Table 5. Results by Age

\begin{tabular}{lllllll}
\multicolumn{1}{c}{ Factors } & Age & N & Mean & STD & $\begin{array}{c}\text { F } \\
\text { value }\end{array}$ & Sig. \\
\hline $\begin{array}{l}\text { Natural Up to } 18 \\
\text { Beauty and }\end{array}$ & 1 & 3.5714 & .986 & \\
Restful & & & & & 400 \\
Atmos- & & & & & & \\
phere & & & & & &
\end{tabular}

phere

$\begin{array}{lccc}18-40 & 122 & 3.8453 & .66042 \\ 41-60 & 67 & 3.6844 & .57710 \\ \text { above 60 } & 18 & 3.7235 & .77446\end{array}$

Hygiene Up to $18 \quad 1 \quad 4.0000$. 190 and Sanita-

tion

$\begin{array}{llll}18-40 & 122 & 2.6878 & .77610 \\ 41-60 & 67 & 2.6493 & .70450 \\ \text { above 60 } & 18 & 2.4583 & .58943\end{array}$

Accommo- Up to $18 \quad 1 \quad 4.0000 \quad$. $3.218024^{* *}$

dation and

Security

$\begin{array}{lccc}18-40 & 122 & 3.4102 & .66317 \\ 41-60 & 67 & 3.1858 & .64958 \\ \text { above 60 } & 17 & 3.0206 & .63222\end{array}$

Hospitality Up to $18 \quad 1 \quad 3.6667 \quad$. $\quad \begin{array}{llllll} & 1 & & .894 & .445\end{array}$

and Infor-

mation

$\begin{array}{lccc}18-40 & 122 & 3.2650 & .71478 \\ 41-60 & 67 & 3.2040 & .61943 \\ \text { above } 60 & 18 & 3.0093 & .71050\end{array}$

Emergency

$\begin{array}{llll}\text { and CaringUp to } 18 \quad 1 & 2.0000 & .896\end{array}$

Facility

\begin{tabular}{|c|c|c|}
\hline $18-40$ & $122 \quad 2.3361$ & .72569 \\
\hline $41-60$ & 2.2537 & .93084 \\
\hline above 6 & 2.3056 & .78850 \\
\hline $\begin{array}{l}\text { Shopping Up to } 18 \\
\text { and activi- }\end{array}$ & 4.0000 & $6.246 \quad .000^{* *} .000^{* *}$ \\
\hline $18-40$ & 3.3648 & .57509 \\
\hline $41-60$ & $\begin{array}{ll}67 & 3.1493\end{array}$ & .54366 \\
\hline above 60 & $18 \quad 2.8333$ & .56880 \\
\hline
\end{tabular}

Significance at the 0.05 level

Table 5 shows tourists' perception based on age varied on Factor 3, Accommodation and security $(\mathrm{F}=3.218, \mathrm{p}=0.024)$ and Factor 6, Shopping and activities $(\mathrm{F}=6.246, \mathrm{p}=0.000)$. For factor 3 the age group up to 18 perception is positive $(\mathrm{M}$ $=4.00)$ than age group above $60(\mathrm{M}=3.02)$ and for factor 6 the age group up to 18 perception is positive $(\mathrm{M}=4.00)$ than age group above $60(\mathrm{M}=2.83)$. Thus, hypothesis 2 has been rejected for factor 3 and 6 and accepted for others.

\section{Recommendations of THE Study}

The findings of the study explain the tourists' perception towards the Cox's Bazar sea beach in Bangladesh, as a tourist destination. From the theoretical point of view, this study has several implications which can be added to the growing body of literature on tourism research.

- The study revealed that tourists perceived some attributes at Cox's Bazaar sea beach highly favorable and favorable ways, as well as they hold unfavorable perception towards some attributes [Table-1]. The study suggests that policy makers, marketers and patrons should keep maintain highly favorable attributes and should improve unfavorable attributes. They should take the necessary actions to improve the current services and facilities provided at the beach tourism in the effort to change and increase the perception of the tourists, and thus further heighten their interest in visiting these places in the future. 
- The study showed that overall perception of tourists towards Cox's Bazar sea beach is favorable on factor 1, Natural Beauty and Restful Atmosphere, factor 3, Accommodation and security, factor 4, Hospitality and information and factor 6, Shopping and activities facilities. On the other hand tourists' perception is unfavorable on factor 2, Hygiene and Sanitation and factor 5, Emergency and Caring services. [Table-3]. This finding can be useful to the planners and marketers of Sea beach tourism at Cox's Bazar in formulating strategies to maintain or enhance their competitiveness. Therefore, tourism managers and marketers should give more attention to ensure up to mark services on composite factors such as Hygiene and sanitation facilities and Emergency and caring services. In planning these facilities, identity and biodiversity of the area must be considered since tourists pay great attention to feel the nature of sea areas.

- The findings of the current research suggest that there is statistically significant difference in tourists' perception respects of respondents' demographic characteristics such as respondents' gender, age, occupation and education on some services and facilities at Cox's Bazar. This finding have a number of implications, particularly for the practitioners in tourism industry, government and non-governmental organizations, as well as other market players for planning and marketing in the industry. Therefore, differentiated marketing strategies should be stressed and executed by the relevant parties. Key player in the beach tourism host, tour operators and stake holders have pursued successful positioning strategies which have been driven by effective market segmentation and brand management.

- Apart from above suggestions, such a new approach is not sufficient if these ideas are not implemented effectively. Therefore, marketers and promoters of this destination should stress on carrying out promotional campaigns of Cox's Bazar sea beach in Bangladesh as a world longest sea beach. Hence, these suggestions are hoped to assist both managers and marketers of the Cox's Bazaar sea beach as a destinations in Bangladesh to gain a better understanding of the different perceptions hold by the local and foreign tourists, and thus implement more strategic marketing decisions.

\section{CONCLUSION}

Cox's Bazar sea beach is the most attractive and highly visited tourist destination in Bangladesh and it has significant socio economic contribution to the local community as well as country. The overall perception of tourists' towards the various facilities and services are mixed. The study showed that overall perception of tourists towards Cox's bazaar sea beach is favorable on Natural Beauty and Restful Atmosphere, Accommodation and security, Hospitality and information and Shopping and activities facilities. On the other hand tourists' perception is unfavorable on Hygiene and Sanitation, Emergency and Caring services. The tourism policy makers and marketers should provide and ensure up to mark services to in areas of services and facilities which are perceived by tourists somewhat poor. It is mentioned as limitation that the respondents' views were taken only from local and national tourists and ignored foreign tourists. Hence, it is recommended that future research incorporate a survey which will also include opinion from foreign tourists.

\section{REFERENCES}

[1] Ahammed, Sheikh Saleh, 2010. "Impact of Tourism in Cox's Bazar, Bangladesh" Masters Thesis, Master in Public Policy and Governance Program, Department of General and Continuing Education, North South University, Bangladesh.

[2] Azam, Shah \& Ahmed Feroj, 2010. "Factors Affecting the Selection of Tour Destination in Bangladesh: An Empirical Analysis" International journal of Business and Management, Vol5, No3, March 2010.

[3] Charlotte M. Echtner and J.R. Brent Ritchie, "The Meaning and Measurement of Destination Image", The Journal Of Tourism Studies Vol. 14, No. 1, May '0337

[4] Hasan, Md Kamrul and et al,2008."An appraisal of foreign tourist arrivals' trend in Bangladesh" Prime University Journal, Vol. 2, No. 2, JulyDecember, 2008

[5] Hasan, S.R,1992. Problems and Prospects of Bangladesh Tourism Industry in Bangladesh, Bureau of Business Research, University of Dhaka, pp. 14-15.

[6] Hasan, S.R. \& Chawdhury, A.I.,1995. "Hotel and Restaurant Services and the development of tourism in Bangladesh", Journal of Business Studies, Dhaka University. 14(1):47-67

[7] Islam, Md. Nazrul and Kamrul, 2009. "Status of Bangladesh in SAARC Tourism: A study on Foreign Tourist Arrival", South East University Journal of Business Studies, Vol.V2, No. 1, January-June, 2009.

[8] Jin Huh, 2002. "Tourist Satisfaction With Cultural / Heritage Sites: The Virginia Historic Triangle" Masters Thesis in Hospitality and Tourism Management, Virginia Polytechnic Institute and State University.

[9] Kamenidou, et al, "Measuring Destination Image and Consumer Choice Criteria: The Case of Mykonos Island", MPRA Paper No. 25420, posted 24. September 2010

[10] Kamal, M.M. \& Chowdhury, A.l. 1993. "Marketing Orientation in Tourism Sectors: Case study of Biman Bangladesh Airlines", Journal of Business Studies, Dhaka University. 14(1): 47-67.

[11] Mir Sofique Abdul and Jannat Ara Parvin, 2009. “Economic Prospects and Constraints of Cox's Bazar Bangladesh - A Study", South Asian Journal of Tourism and Heritage (2009), Vol. 2, No. 1.

[12] Mahboob, Muhammad Ali, 2008. "Different aspects of Tourism marketing strategies with special reference to Bangladesh: An Analysis" Published in Business Review, A Journal of Business Administration, Khulna University, Vol.6, No.1\&2, January-Decmber, 2008.

[13] Md. Ashraful Islam Chowdhury, "Tourism Industry in Bangladesh; A Brief Diagnosis and Prescriptions for Appropriate Development", The daily star online publication, Dhaka, 30 July 2009 04:18.

[14] Odunga, Pius, 2005. PhD-thesis on"Choice of Attractions, Expenditure and Satisfaction of International Tourists to Kenya" Wageningen University.

[15] Ramazan AksoyA, 2011. "Destination Image As a Type of Image and Measuring Destination Image in Tourism (Amasra Case)", European Journal of Social Sciences - Volume 20, Number 3 (2011)

[16] Yue Hou, 2009. "An Investigation into Visitors' Satisfaction With Port Elizabeth's Heritage Museums" Maters Thesis, Faculty of Business and Economic Sciences, Nelson Mandela Metropolitan University.

[17] Schiffman, Leon G. and Kannk Leslic L. 2004. Consumer Behavior: Building Marketing Strategy, 10th edition Mc Gran - Hill Irwin, Boston, Page-pp 170

[18] Robertson Thomas S, 1984. Consumer Behavior, Scott. Foresman and Company, Dalas, Texas, page-166. 